\title{
Sustainable Development and Fund Generation - A Study among Library Professionals Working in Select Higher Education Institutions in and around Chennai
}

\author{
S. Gopalakrishnan ${ }^{1 *}$ and T. M. Kalpana ${ }^{2}$ \\ 'National Institute of Fashion Technology, Taramani, Chennai - 600113, Tamil Nadu, India; gopusg@yahoo.com \\ IIndian Statistical Insitute, Taramani, Chennai - 600113,Tamil Nadu, India; kalpana.ttcpl@gmail.com
}

\begin{abstract}
Libraries are evolving itself according to the technologically changing scenario. A library and Information Science (LIS) professional are aware of modern technologies but finds it difficult to implement due to financial constraints. This study focused on adaptability of sustainable development, need for fund generation, awareness, implementation strategies, its advantages and disadvantages with specific reference to implementation in libraries. 60 questionnaires were distributed among library professionals working in select higher educational institutions in and around Chennai. It is found that more significance was given to raise the fund through sustainable development. The study, envisages that sustainable development and fund generation should be popularized more among LIS professionals due to decrease in funds and increase in recurring cost ( $83 \%$ of the respondents) of the library.
\end{abstract}

Keywords: Fund Generation, LIS Professionals, Sustainable Development

\section{Introduction}

Sustainable development is a continuous and long term development in common. Report on World Commission on Environment and Development: Our Common Future, Brundtl and Bericht [1] has explained that "development that meets the needs of the present without compromising the ability of future generations to meet their own needs". Evolutionary changes in Libraries like digital and print resource management, accessibility, security, modernization, Infrastructure development needs knowledgeable and skilled resources. Modernization requires investment, adaptability, skilled manpower etc. Technological development ends in lots of waste especially e-waste Moreover, it produces lots of waste for dumping especially e-waste. For example, if the RFID technology replaces the existing barcode printers and scanners then it becomes e-waste. Therefore all developments should definitely focus on wastes created out of that improvement. These wastes can be minimized by REUSE, RECYCLE and REDUCE (3Rs) [2], wherever possible. Waste generation cannot be avoided but minimized by economic and efficient usage of resources through 3 Rs and helps to reduce waste generation and investment. With reference to Library environment, adapting sustainable practices suitably can bring in change.

In view of the sustainable development in the library environment, modernization of library and information services have changed drastically after introduction of computer; wireless communication; internet of things etc that has forced to adopt changes according to the recent trends. Information explosion and its availability in multiple and mixed formats has led to the change in user community and service format of the library professionals.

${ }^{*}$ Author for correspondence 


\section{Review of Literature}

Library and information services are helping the users to tackle information inequality demonstrated in the growing information gap and digital divide. Through their services, information on research and innovation is made available to advance sustainable development and the welfare of the libraries. There is a growing concern for the issue of sustainability and social responsibility [3]. A New era of Sustainability states the need and ways of Sustainability in business environment with Social responsibility [4] wherein Kamal [5] proposed that the environment inside the library and workspace is more important and this will definitely increase the productivity and efficiency of human resources. Not just collections, but an excellent environment will attract users to the library. The author also discussed about the necessity and responsibility of Library Professionals in fund raising programmes. An appeal was put forward to the citizens of the State of Philadelphia by The Franklin Institute in 1898. A special committee was set up for collection of endowment fund to upgrade the library infrastructure [6]. Swan, [7] has broadly listed out the ways to get more money for library, practical implementation, and participation of library professionals and emphasized that fund raising motivates to launch a program. Steele \& Elder [8] shows that the major purpose of fund-raising for public libraries is collection development. Commitment is clearly part of any fund-raising campaign. Success in fundraising depends on personal dedication, strategic planning and excellent communication.

\section{Methodology}

A pilot study was conducted among LIS Professionals working in select higher educational institutions in and around Chennai. A structured questionnaire on 5 point scale responses were distributed among 60 LIS Professionals. Various statistical tools such as Mean, Standard Deviation and Reliability analysis were employed using Statistical analytical package IBM SPSS.

\section{Objectives of the Study}

The objectives identified for the study are listed below:

- To evaluate the awareness on concept of sustainable, continuous and long term development among LIS Professionals
- Opinion, familiarity and interest towards sustainable development

- To examine the knowledge updating on recent trends and technological up gradations in other fields

- Has the concept of sustainable development is popular or yet to be reached

- Different strategies of fund generation suitable for libraries of higher education institutions

- If sustainability measures are made mandatory will it be fruitful

- Evaluation of opinion of working professionals on level of co-operation from management if such implementations are initiated by LIS Professionals

\section{Hypotheses}

Based on the objectives the following hypotheses are framed:

- LIS professionals working in Higher Educational Institutions are aware of fund generation and its significance

- There exists difference among respondents in fund generation

- Different factors contribute to need for sustainable development

- Level of implementation depends on the support and managerial decisions of the parent institution

\section{Analysis and Discussion}

A total of 60questionnaires were distributed to the LIS professionals working in 40 select higher education institutions in and around Chennai. The institutions were classified based on their domain as Engineering and Technology, Arts and Sciences, Medical sciences, and Multi domain Universities (Table 1). Table 1 reveals that the response rate from respondents is $78.33 \%$.

Further the study was classified based on gender, age, designation and experience which is shown in Table 2.

$59.6 \%$ belongs to male and $40.4 \%$ belongs to female aggregates to around 3:2 ratio. Further respondents were classified under designation as librarian and assistant librarian, $40.4 \%$ and $59.6 \%$ respectively. It is inferred that in many organizational structure, two or more Assistant Librarians work under one Librarian and this may be the reason that Assistant Librarians are comparatively more. More than $75 \%$ of respondents are in the age group of 
Table 1. Quantum of Questionnaire Distributed and Responses Received

\begin{tabular}{|c|c|c|c|c|c|}
\hline $\begin{array}{r}\text { Sl. } \\
\text { No. }\end{array}$ & $\begin{array}{c}\text { Domain of } \\
\text { Institutions }\end{array}$ & $\begin{array}{c}\text { No. of } \\
\text { Institutions }\end{array}$ & Distributed & Received & Percentage \\
\hline 1 & $\begin{array}{c}\text { Engineering } \\
\text { \& } \\
\text { Technology }\end{array}$ & 15 & 25 & 20 & 80.00 \\
\hline 2 & $\begin{array}{c}\text { Arts \& } \\
\text { Science }\end{array}$ & 10 & 15 & 13 & 86.67 \\
\hline 3 & $\begin{array}{c}\text { Medical } \\
\text { Sciences* }\end{array}$ & 10 & 10 & 08 & 80.00 \\
\hline 4 & $\begin{array}{c}\text { Multi } \\
\text { domain } \\
\text { Universities }\end{array}$ & 5 & 10 & 6 & 60.00 \\
\hline & Total & 40 & 60 & 47 & 76.67 \\
\hline
\end{tabular}

*Medical Sciences includes Medical, Dental, Pharmacy and Nursing

Table 2. Demographic Details of respondents

\begin{tabular}{|c|c|c|c|c|c|c|}
\hline S1.No. & Description & $\begin{array}{c}\text { Engineering } \\
\& \\
\text { Technology }\end{array}$ & $\begin{array}{l}\text { Arts \& } \\
\text { Science }\end{array}$ & $\begin{array}{l}\text { Medical } \\
\text { Sciences }\end{array}$ & \begin{tabular}{|c|} 
Multi- \\
domain \\
Universities
\end{tabular} & Total \\
\hline & \multicolumn{6}{|c|}{ Gender } \\
\hline 1 & Male & 12 & 4 & 7 & 5 & $\begin{array}{c}28 \\
(59.6)\end{array}$ \\
\hline \multirow[t]{2}{*}{2} & Female & 8 & 9 & 1 & 1 & $\begin{array}{c}19 \\
(40.4)\end{array}$ \\
\hline & \multicolumn{6}{|c|}{ Age (in yrs) } \\
\hline 1 & 21to 30 & 0 & 3 & 0 & 0 & $3(6.4)$ \\
\hline 2 & 31 to 40 & 4 & 3 & 2 & 0 & $9(19.1)$ \\
\hline 3 & 41 to 50 & 9 & 5 & 3 & 6 & $\begin{array}{c}23 \\
(48.9)\end{array}$ \\
\hline 4 & Above 50 & 7 & 2 & 3 & 0 & $\begin{array}{c}12 \\
(25.5)\end{array}$ \\
\hline & \multicolumn{6}{|c|}{ Designation } \\
\hline 1 & $\begin{array}{c}\text { Asst. } \\
\text { Librarian }\end{array}$ & 13 & 4 & 6 & 5 & $\begin{array}{c}28 \\
(59.6) \\
\end{array}$ \\
\hline 2 & Librarian & 7 & 9 & 2 & 1 & $\begin{array}{c}19 \\
(40.4)\end{array}$ \\
\hline & \multicolumn{6}{|c|}{ Years of Experience } \\
\hline 1 & Below 5 & 0 & 2 & 0 & 0 & $2(4.3)$ \\
\hline 2 & 6 to 10 & 3 & 5 & 3 & 5 & $\begin{array}{c}16 \\
(34.0)\end{array}$ \\
\hline 3 & 11 to 15 & 6 & 2 & 2 & 1 & $\begin{array}{c}11 \\
(23.4) \\
\end{array}$ \\
\hline 4 & 16 to 20 & 4 & 2 & 2 & 0 & $8(17.0)$ \\
\hline 5 & Above 20 & 7 & 2 & 1 & 0 & $\begin{array}{c}10 \\
(21.3) \\
\end{array}$ \\
\hline & Total & 20 & 13 & 8 & 6 & $\begin{array}{c}47 \\
(100.00)\end{array}$ \\
\hline
\end{tabular}

41 and above and $21.3 \%$ of the respondents are having more than 20 years of experience. It is also interesting to note that, the maximum respondents are of asst. librarian (13) are from Engineering and Technology institutions, followed by Medical sciences (6).

\section{Reliability Analysis}

Reliability analysis is a test on collected data to ensure that the data collected has reliable responses. The exploratory nature of the study has necessitated for data reliability analysis to check whether the items used in the measures are tapping to the same concept or not. Such test accomplished through the use of factor analysis. According to Coakes and Steed [9], factor analysis is a data reduction technique used to reduce large number of variables to a smaller set of underlying set of similar factors to summarize the essential information essential in the variables. Two popular methods in factor analysis are Principal Components and Principal Axis Factoring. In this study, Principal components method is adapted and applied to all variables that has more variables for analysis.

Reliability is concerned with consistency of the variable. There are two identifiable aspects of this issue, namely external and internal reliability. Widely used method in estimating internal reliability is Cronbach's Alpha ( $\alpha$ ). The Formula used is

$$
\alpha=\frac{K}{K-1}\left(1-\frac{\sum_{i=1}^{K} \sigma_{Y_{i}}^{2}}{\sigma_{X}^{2}}\right)
$$

A commonly accepted rules for describing internal consistency using Cronbach's Alpha[10] are $\alpha>=0.9$ (Excellent), $0.9>=\alpha>=0.8$ (Good), $0.8>=\alpha>=0.7$ (Acceptable), $0.7>=\alpha>=0.6$ (Questionable), $0.6>=\alpha>=$ 0.5 (Poor), $0.5>\alpha$ (Unacceptable). The data thus collected from LIS professionals, were analyzed on four concepts namely "Views on Sustainability", "Importance of sustainable development" "Awareness on Sustainable Development" and "Sustainable Development and Fund Generation". Under each concept, proportionate number of variables was taken up for obtaining the views of LIS professionals. The Concepts taken up for the study, variables and the Cronbach's Alpha value are shown in Table 3.

According to the Cronbach's Alpha value, data collected shows more or less of 0.7 for all groups. This indicates that the responses are acceptable and the study is acceptable in nature. 


\subsection{Views on Sustainable Development}

Respondents views on sustainable development has been estimated based on five variables in a five point scale such as "Strongly Agree", "Agree", "No Comments", "Disagree" and "Strongly Disagree" and the responses are shown in Table 4. Mean and Standard Deviation (Std.) were calculated based on a five point scale. The ranks were assigned accordingly based on the mean value.

It can be observed from the table that LIS professionals feel that sustainable development is beneficial with $93.6 \%$ professionals has agreed or strongly agreed followed by "strategic part of service" meaning that sustainability development should not be differentiated from regular library services with $87.3 \%$ of agreed in responses. Minimal

Table 3. Reliability analysis - Alpha Value

\begin{tabular}{|c|c|c|c|}
\hline Sl. No & Concept & $\begin{array}{c}\text { No. of } \\
\text { Variables }\end{array}$ & Alpha Value \\
\hline 1 & $\begin{array}{c}\text { View on Sustainable } \\
\text { Development }\end{array}$ & 5 & 0.618 \\
\hline 2 & $\begin{array}{l}\text { Awareness on } \\
\text { Sustainable } \\
\text { Development }\end{array}$ & 10 & 0.783 \\
\hline 3 & $\begin{array}{c}\text { Sustainable } \\
\text { Development and Fund } \\
\text { Generation }\end{array}$ & 10 & 0.743 \\
\hline
\end{tabular}

Table 4. Views on Sustainable Development

\begin{tabular}{|c|c|c|c|c|c|c|c|c|c|}
\hline S.No & Description & SA & A & NC & D & SD & Mean & Std. & Rank \\
\hline 1 & $\begin{array}{l}\text { Something } \\
\text { that could be } \\
\text { beneficial }\end{array}$ & $\begin{array}{c}23 \\
(48.9)\end{array}$ & $\begin{array}{c}21 \\
(44.7)\end{array}$ & $\begin{array}{c}2 \\
(4.3)\end{array}$ & $\begin{array}{c}1 \\
(2.1)\end{array}$ & 0 & 4.40 & .681 & 1 \\
\hline 2 & $\begin{array}{c}\text { Strategic } \\
\text { part of } \\
\text { service }\end{array}$ & $\begin{array}{c}17 \\
(36.2)\end{array}$ & $\begin{array}{c}24 \\
(51.1)\end{array}$ & $\begin{array}{c}5 \\
(10.6)\end{array}$ & $\begin{array}{c}1 \\
(2.1)\end{array}$ & 0 & 4.23 & .666 & 3 \\
\hline 3 & $\begin{array}{c}\text { A } \\
\text { management } \\
\text { fad }\end{array}$ & $\begin{array}{c}12 \\
(25.5)\end{array}$ & $\begin{array}{c}18 \\
(38.3)\end{array}$ & $\begin{array}{c}16 \\
(34.0)\end{array}$ & $\begin{array}{c}1 \\
(2.1)\end{array}$ & 0 & 3.87 & .824 & 5 \\
\hline 4 & $\begin{array}{l}\text { Already in } \\
\text { the library } \\
\text { but not } \\
\text { under the } \\
\text { same }\end{array}$ & $\begin{array}{c}14 \\
(29.8)\end{array}$ & $\begin{array}{c}25 \\
(53.2)\end{array}$ & $\begin{array}{c}7 \\
(14.9)\end{array}$ & $\begin{array}{c}1 \\
(2.1)\end{array}$ & 0 & 4.11 & .729 & 4 \\
\hline 5 & $\begin{array}{l}\text { It is a } \\
\text { familiar } \\
\text { term }\end{array}$ & $\begin{array}{c}19 \\
(40.4)\end{array}$ & $\begin{array}{c}24 \\
(51.1)\end{array}$ & $\begin{array}{c}4 \\
(8.5)\end{array}$ & 0 & 0 & 4.32 & .629 & 2 \\
\hline
\end{tabular}

(SA Strongly Agree; A Agree; NC No Comments; D Disagree; SD Strongly Disagree) respondents i.e $12.7 \%$ gave no opinion, disagree and strongly disagree put together. Moreover, many respondents agree that it is a familiar term, but it is not practiced under the same name as Sustainable Development. But definitely, sustainable development is not a management fad.

It can be seen from Table 5 that the views on sustainable development differs from the designation as well as on gender wise. The order of the first top two preferences "Something that could be beneficial" and "It is a familiar term" are interchanged between the professionals' librarian and assistant librarian and same interchange could be seen on gender also. However, in all the categories, the least preferences are same in the case of designation as well as gender. It is inferred that either the designation or the gender give much importance in the views on "A management fad" and "Already in the library but not under the same".

Female and librarian have indicated that the "Sustainable Development is beneficial" with top priority. Male and assistant librarian has indicated that "sustainable development is a familiar term" Male, female, librarian and assistant librarian has unanimously pointed out that "sustainable development is already practiced in libraries" and "sustainable development is not a management fad"

\subsection{Awareness on Sustainable Development}

Awareness on Sustainable Development has been ascertained from the LIS professionals and their opinion is tabulated in Table 6.

It could be seen from Table 6 that about $95.7 \%$ of responses show that awareness on free open source should be created and it is evident that if the management of the parent institution co-operates and supports the LIS professionals, libraries will be motivated to implement sustainable measures. This can be evaluated from the $95.7 \%$ of respondents indicating "agree" or "strongly agree". Secondly, many professionals have felt that more awareness should be created on availability on Free Open Source software and resources to upgrade the efficiency of library services. Structural engineering was voted as least that could save energy, as awareness on these strategies is comparatively less. But, most of libraries are already built thus renovation or remodeling, may not be easily implemented. Moreover, architectural design needs lot of knowledge on civil engineering evaluation to location, sunlight, ventilation, direction of wind etc. But more 
Table 5. Views on Sustainable Development vs. Designation and Gender

\begin{tabular}{|c|c|c|c|c|c|c|c|c|c|c|c|c|c|}
\hline \multirow{3}{*}{ Sl. No } & \multirow{3}{*}{ Description } & \multicolumn{6}{|c|}{ Designation } & \multicolumn{6}{|c|}{ Gender } \\
\hline & & \multicolumn{3}{|c|}{ Librarian } & \multicolumn{3}{|c|}{ Asst. Librarian } & \multicolumn{3}{|c|}{ Male } & \multicolumn{3}{|c|}{ Female } \\
\hline & & Mean & Std. & Rank & Mean & Std. & Rank & Mean & Std. & Rank & Mean & Std. & Rank \\
\hline 1 & $\begin{array}{l}\text { Something } \\
\text { that could be } \\
\text { beneficial }\end{array}$ & 4.63 & .496 & 1 & 4.25 & .752 & 2 & 4.36 & .678 & 2 & 4.47 & .697 & 1 \\
\hline 2 & $\begin{array}{c}\text { Strategic } \\
\text { part of } \\
\text { service }\end{array}$ & 4.26 & .562 & 3 & 4.21 & .738 & 3 & 4.32 & .612 & 3 & 4.11 & .737 & 3 \\
\hline 3 & $\begin{array}{c}\mathrm{A} \\
\text { management } \\
\text { fad }\end{array}$ & 3.68 & .885 & 5 & 4.00 & .770 & 5 & 4.07 & .858 & 5 & 3.58 & .692 & 5 \\
\hline 4 & $\begin{array}{l}\text { Already in } \\
\text { the library } \\
\text { but not } \\
\text { under the } \\
\text { same }\end{array}$ & 4.16 & .688 & 4 & 4.07 & .766 & 4 & 4.29 & .600 & 4 & 3.84 & .834 & 4 \\
\hline 5 & $\begin{array}{l}\text { It is a } \\
\text { familiar } \\
\text { term }\end{array}$ & 4.37 & .684 & 2 & 4.29 & .600 & 1 & 4.43 & .573 & 1 & 4.16 & .688 & 2 \\
\hline
\end{tabular}

Table 6. Awareness on Sustainable Development

\begin{tabular}{|c|c|c|c|c|c|c|c|c|c|}
\hline $\begin{array}{l}\text { S. } \\
\text { No }\end{array}$ & Particulars & SA & A & NC & $\mathrm{D}$ & SD & Mean & Std. & Rank \\
\hline 1 & $\begin{array}{l}\text { Sustainable development should be popularized } \\
\text { among Library professionals }\end{array}$ & $\begin{array}{c}19 \\
(40.4)\end{array}$ & $\begin{array}{c}21 \\
(44.7)\end{array}$ & $1(2.1)$ & $\begin{array}{c}3 \\
(6.4) \\
\end{array}$ & $\begin{array}{c}3 \\
(6.4)\end{array}$ & 4.06 & 1.131 & 9 \\
\hline 2 & Awareness should be created on fund generation & $\begin{array}{c}20 \\
(42.6)\end{array}$ & $\begin{array}{c}22 \\
(46.8)\end{array}$ & $2(4.3)$ & $\begin{array}{c}1 \\
(2.1)\end{array}$ & $\begin{array}{c}2 \\
(4.3)\end{array}$ & 4.21 & .954 & 4 \\
\hline 3 & $\begin{array}{c}\text { Awareness should be created on economic } \\
\text { utilization of energy }\end{array}$ & $\begin{array}{c}23 \\
(48.9)\end{array}$ & $\begin{array}{c}16 \\
(34.0)\end{array}$ & $\begin{array}{c}5 \\
(10.6) \\
\end{array}$ & $\begin{array}{c}2 \\
(4.3)\end{array}$ & $\begin{array}{c}1 \\
(2.1)\end{array}$ & 4.23 & .960 & 3 \\
\hline 4 & $\begin{array}{l}\text { Awareness should be created on usage of Free } \\
\text { Open Source Software and resources for library } \\
\text { professionals }\end{array}$ & $\begin{array}{c}19 \\
(40.4)\end{array}$ & $\begin{array}{c}26 \\
(55.3)\end{array}$ & $1(2.1)$ & 0 & $\begin{array}{c}1 \\
(2.1)\end{array}$ & 4.32 & .726 & 1 \\
\hline 5 & $\begin{array}{c}\text { Awareness should be created on significance of } \\
\text { structural engineering that saves energy through } \\
\text { natural light etc. }\end{array}$ & $\begin{array}{c}10 \\
(21.3)\end{array}$ & $\begin{array}{c}32 \\
(68.3)\end{array}$ & $3(6.4)$ & $\begin{array}{c}1 \\
(2.1)\end{array}$ & $\begin{array}{c}1 \\
(2.1)\end{array}$ & 4.04 & .751 & 10 \\
\hline 6 & $\begin{array}{l}\text { Librarian should try to popularize and implement } \\
\text { environment friendly technologies }\end{array}$ & $\begin{array}{c}20 \\
(42.6)\end{array}$ & $\begin{array}{c}21 \\
(44.7)\end{array}$ & $2(4.3)$ & $\begin{array}{c}3 \\
(6.4) \\
\end{array}$ & $\begin{array}{c}1 \\
(2.1)\end{array}$ & 4.19 & .947 & 6 \\
\hline 7 & $\begin{array}{l}\text { All libraries should self-assess and strategize on } \\
\text { sustainability ratings }\end{array}$ & $\begin{array}{c}13 \\
(27.7)\end{array}$ & $\begin{array}{c}28 \\
(59.6)\end{array}$ & $4(8.5)$ & $\begin{array}{c}2 \\
(4.3)\end{array}$ & 0 & 4.11 & .729 & 8 \\
\hline 8 & $\begin{array}{l}\text { Sustainability formula and equation should be } \\
\text { revisited in libraries on regular intervals }\end{array}$ & $\begin{array}{c}19 \\
(40.4)\end{array}$ & $\begin{array}{c}19 \\
(40.4)\end{array}$ & $\begin{array}{c}7 \\
(14.9)\end{array}$ & $\begin{array}{c}1 \\
(2.1)\end{array}$ & $\begin{array}{c}1 \\
(2.1)\end{array}$ & 4.15 & .908 & 7 \\
\hline 9 & $\begin{array}{l}\text { Mandatory policies, standards and certifications } \\
\text { will bring more green library initiatives }\end{array}$ & $\begin{array}{c}19 \\
(40.4)\end{array}$ & $\begin{array}{c}21 \\
(44.7)\end{array}$ & $\begin{array}{c}5 \\
(10.6) \\
\end{array}$ & $\begin{array}{c}1 \\
(2.1) \\
\end{array}$ & $\begin{array}{c}1 \\
(2.1) \\
\end{array}$ & 4.19 & .876 & 5 \\
\hline 10 & $\begin{array}{l}\text { Management co-operation will help in bringing } \\
\text { sustainable development in libraries }\end{array}$ & $\begin{array}{c}23 \\
(48.9)\end{array}$ & $\begin{array}{c}19 \\
(40.4)\end{array}$ & $2(4.3)$ & $\begin{array}{c}2 \\
(4.3)\end{array}$ & $\begin{array}{c}1 \\
(2.1)\end{array}$ & 4.30 & .907 & 2 \\
\hline
\end{tabular}

(SA Strongly Agree; A Agree; NC No Comments; D Disagree; SD Strongly Disagree) 
importance should be given on these skills, at least for the libraries which are planning renovation or remodel of the existing infrastructure. Further Table 7 reveals the awareness on sustainable development against the designation of the respondents.

Table 7 reveals that there are heterogeneous responses from the Librarian and Assistant Librarian. Librarian's responses give more preference that "management cooperation will help in bringing sustainable development in libraries" whereas Assistant Librarian indicated that there importance that "Awareness should be created on economic utilization of energy". Awareness of sustainable development vs designation was enumerated in Table 8.

\subsection{Sustainable Development and Fund Generation}

From the responses indicated by the respondents, it is evident that sustainable development can be attained by

Table 7. Awareness on Sustainable Development Vs. Designation

\begin{tabular}{|c|c|c|c|c|c|c|c|c|c|c|c|c|c|c|c|c|c|}
\hline \multirow{2}{*}{\begin{tabular}{l|} 
Sl. \\
No \\
\end{tabular}} & \multirow{2}{*}{ Description } & \multicolumn{8}{|c|}{ Librarian } & \multicolumn{8}{|c|}{ Assistant Librarian } \\
\hline & & SA & A & $\mathrm{NC}$ & $\mathrm{D}$ & SD & Mean & Std. & Rank & SA & A & $\mathrm{NC}$ & $\mathrm{D}$ & SD & Mean & Std. & Rank \\
\hline 1 & $\begin{array}{c}\text { Sustainable development } \\
\text { should be popularized } \\
\text { among Library professionals }\end{array}$ & 9 & 8 & 0 & 0 & 2 & 4.16 & 1.24 & 8 & 10 & 13 & 1 & 3 & 1 & 4.00 & 1.089 & 10 \\
\hline 2 & $\begin{array}{c}\text { Awareness should be } \\
\text { created on fund generation }\end{array}$ & 11 & 6 & 1 & 0 & 1 & 4.37 & 1.012 & 4 & 9 & 16 & 1 & 1 & 1 & 4.11 & .916 & 7 \\
\hline 3 & $\begin{array}{l}\text { Awareness should be } \\
\text { created on economic } \\
\text { utilization of energy }\end{array}$ & 8 & 7 & 3 & 1 & 0 & 4.16 & .898 & 7 & 15 & 9 & 2 & 1 & 1 & 4.29 & 1.013 & 1 \\
\hline 4 & $\begin{array}{l}\text { Awareness should be } \\
\text { created on usage of Free } \\
\text { Open Source Software } \\
\text { and resources for library } \\
\text { professionals }\end{array}$ & 8 & 11 & 0 & 0 & 0 & 4.42 & .507 & 2 & 11 & 15 & 1 & 0 & 1 & 4.25 & .844 & 2 \\
\hline 5 & $\begin{array}{c}\text { Awareness should be } \\
\text { created on significance } \\
\text { of structural engineering } \\
\text { that saves energy through } \\
\text { natural light etc. }\end{array}$ & 4 & 12 & 2 & 0 & 1 & 3.95 & .911 & 10 & 6 & 20 & 1 & 1 & 0 & 4.11 & .629 & 5 \\
\hline 6 & $\begin{array}{l}\text { Librarian should try to } \\
\text { popularize and implement } \\
\text { environment friendly } \\
\text { technologies }\end{array}$ & 11 & 7 & 0 & 1 & 0 & 4.47 & .772 & 1 & 9 & 14 & 2 & 2 & 1 & 4.00 & 1.018 & 9 \\
\hline 7 & $\begin{array}{l}\text { All libraries should self- } \\
\text { assess and strategize on } \\
\text { sustainability ratings }\end{array}$ & 6 & 10 & 2 & 1 & 0 & 4.11 & .809 & 9 & 7 & 18 & 2 & 1 & 0 & 4.11 & .685 & 6 \\
\hline 8 & $\begin{array}{c}\text { Sustainability formula and } \\
\text { equation should be revisited } \\
\text { in libraries on regular } \\
\text { intervals }\end{array}$ & 7 & 9 & 3 & 0 & 0 & 4.21 & .713 & 5 & 12 & 10 & 4 & 1 & 1 & 4.11 & 1.031 & 8 \\
\hline 9 & $\begin{array}{c}\text { Mandatory policies, } \\
\text { standards and certifications } \\
\text { will bring more green } \\
\text { library initiatives }\end{array}$ & 7 & 9 & 3 & 0 & 0 & 4.21 & .713 & 5 & 12 & 12 & 2 & 1 & 1 & 4.18 & .983 & 4 \\
\hline 10 & $\begin{array}{l}\text { Management co-operation } \\
\text { will help in bringing } \\
\text { sustainable development in } \\
\text { libraries }\end{array}$ & 13 & 4 & 0 & 1 & 1 & 4.42 & 1.121 & 3 & 10 & 15 & 2 & 1 & 0 & 4.21 & .738 & 3 \\
\hline
\end{tabular}


Table 8. Awareness of sustainable development vs. designation

\begin{tabular}{|c|c|c|c|c|c|c|c|}
\hline Sl. & \multirow{2}{*}{ Description } & \multicolumn{3}{|c|}{ Librarian } & \multicolumn{3}{|c|}{ Assistant Librarian } \\
\hline No & & Mean & Std. & Rank & Mean & Std. & Rank \\
\hline 1 & $\begin{array}{l}\text { Sustainable development should be popularized } \\
\text { among Library professionals }\end{array}$ & 4.16 & 1.24 & 8 & 4.00 & 1.089 & 10 \\
\hline 2 & Awareness should be created on fund generation & 4.37 & 1.012 & 4 & 4.11 & .916 & 7 \\
\hline 3 & $\begin{array}{c}\text { Awareness should be created on economic } \\
\text { utilization of energy }\end{array}$ & 4.16 & .898 & 7 & 4.29 & 1.013 & 1 \\
\hline 4 & $\begin{array}{c}\text { Awareness should be created on usage of Free } \\
\text { Open Source Software and resources for library } \\
\text { professionals }\end{array}$ & 4.42 & .507 & 2 & 4.25 & .844 & 2 \\
\hline 5 & $\begin{array}{c}\text { Awareness should be created on significance of } \\
\text { structural engineering that saves energy through } \\
\text { natural light etc. }\end{array}$ & 3.95 & .911 & 10 & 4.11 & .629 & 5 \\
\hline 6 & $\begin{array}{c}\text { Librarian should try to popularize and implement } \\
\text { environment friendly technologies }\end{array}$ & 4.47 & .772 & 1 & 4.00 & 1.018 & 9 \\
\hline 7 & $\begin{array}{l}\text { All libraries should self-assess and strategize on } \\
\text { sustainability ratings }\end{array}$ & 4.11 & .809 & 9 & 4.11 & .685 & 6 \\
\hline 8 & $\begin{array}{l}\text { Sustainability formula and equation should be } \\
\text { revisited in libraries on regular intervals }\end{array}$ & 4.21 & .713 & 5 & 4.11 & 1.031 & 8 \\
\hline 9 & $\begin{array}{c}\text { Mandatory policies, standards and certifications } \\
\text { will bring more green library initiatives }\end{array}$ & 4.21 & .713 & 5 & 4.18 & .983 & 4 \\
\hline 10 & $\begin{array}{l}\text { Management co-operation will help in bringing } \\
\text { sustainable development in libraries }\end{array}$ & 4.42 & 1.121 & 3 & 4.21 & .738 & 3 \\
\hline
\end{tabular}

Table 9. Sustainable development and fund generation

\begin{tabular}{|c|c|c|c|c|c|c|c|c|c|}
\hline Sl. No & Particulars & SA & A & NC & $\mathrm{D}$ & SD & Mean & Std. & Rank \\
\hline 1 & Management or recurring cost is increasing & $\begin{array}{c}19 \\
(40.4)\end{array}$ & $\begin{array}{c}18 \\
(38.3)\end{array}$ & \begin{tabular}{c|c}
6 \\
$(12.8)$
\end{tabular} & $3(6.4)$ & $\begin{array}{c}1 \\
(2.1)\end{array}$ & 4.09 & .996 & 5 \\
\hline 2 & Sustainable development can be attained by fund generation & $\begin{array}{c}15 \\
(31.9) \\
\end{array}$ & $\begin{array}{c}27 \\
(57.4) \\
\end{array}$ & \begin{tabular}{|c|}
4 \\
$(8.5)$
\end{tabular} & $1(2.1)$ & 0 & 4.19 & 0.680 & 1 \\
\hline 3 & $\begin{array}{l}\text { Sustainable development can be attained by economic usage } \\
\text { and saving }\end{array}$ & $\begin{array}{c}20 \\
(42.6) \\
\end{array}$ & \begin{tabular}{c|}
22 \\
$(46.8)$
\end{tabular} & 0 & $4(8.5)$ & $\begin{array}{c}\mathrm{I} \\
(2.1)\end{array}$ & 4.19 & 0.970 & 2 \\
\hline 4 & $\begin{array}{l}\text { Physical advertisings in library campus can be allowed for } \\
\text { income generation }\end{array}$ & $\begin{array}{c}5 \\
(10.6)\end{array}$ & \begin{tabular}{c|}
23 \\
$(48.9)$
\end{tabular} & \begin{tabular}{c|}
13 \\
$(27.7)$
\end{tabular} & $\begin{array}{c}6 \\
(12.8)\end{array}$ & 0 & 3.57 & 0.853 & 10 \\
\hline 5 & $\begin{array}{c}\text { Book donation camps can be allowed for collection } \\
\text { development }\end{array}$ & $\begin{array}{c}17 \\
(36.2)\end{array}$ & $\begin{array}{c}24 \\
(51.1) \\
\end{array}$ & \begin{tabular}{c|}
3 \\
$(6.4)$
\end{tabular} & $1(2.1)$ & $\begin{array}{c}2 \\
(4.3) \\
\end{array}$ & 4.13 & 0.947 & 3 \\
\hline 6 & Collection of endowment funds from users & $\begin{array}{c}15 \\
(31.9) \\
\end{array}$ & \begin{tabular}{c|}
25 \\
$(53.2)$ \\
\end{tabular} & \begin{tabular}{c|c|}
5 \\
$(10.6)$ \\
\end{tabular} & $1(2.1)$ & $\begin{array}{c}1 \\
(2.1) \\
\end{array}$ & 4.11 & .840 & 4 \\
\hline 7 & $\begin{array}{l}\text { Collected Endowment funds should be invested and interest } \\
\text { alone should be utilized }\end{array}$ & $\begin{array}{c}7 \\
(14.9) \\
\end{array}$ & \begin{tabular}{c|}
37 \\
$(78.7)$ \\
\end{tabular} & \begin{tabular}{c|c}
1 \\
$(2.1)$
\end{tabular} & $1(2.1)$ & $\begin{array}{c}1 \\
(2.1) \\
\end{array}$ & 4.02 & 0.675 & 6 \\
\hline 8 & $\begin{array}{l}\text { Paid extension or reference services to non-members can be } \\
\text { provided }\end{array}$ & $\begin{array}{c}10 \\
(21.3) \\
\end{array}$ & $\begin{array}{c}27 \\
(57.4) \\
\end{array}$ & \begin{tabular}{c|c}
5 \\
$(10.6)$
\end{tabular} & $3(6.4)$ & $\begin{array}{c}2 \\
(4.3)\end{array}$ & 3.85 & 0.978 & 7 \\
\hline 9 & $\begin{array}{l}\text { Paid internet services for non-members in lean period can be } \\
\text { permitted }\end{array}$ & $\begin{array}{c}15 \\
(31.9) \\
\end{array}$ & $\begin{array}{c}17 \\
(36.2)\end{array}$ & \begin{tabular}{c|}
7 \\
$(14.9)$ \\
\end{tabular} & $\begin{array}{c}7 \\
(14.9) \\
\end{array}$ & $\begin{array}{c}1 \\
(2.1)\end{array}$ & 3.81 & 1.116 & 8 \\
\hline 10 & $\begin{array}{l}\text { Individual membership on paid basis to students from other } \\
\text { educational institutions can be encouraged }\end{array}$ & $\begin{array}{c}12 \\
(25.5)\end{array}$ & $\begin{array}{c}23 \\
(48.9)\end{array}$ & \begin{tabular}{c|}
7 \\
$(14.9)$
\end{tabular} & $1(2.1)$ & $\begin{array}{c}4 \\
(8.5)\end{array}$ & 3.81 & 1.116 & 8 \\
\hline
\end{tabular}

(SA Strongly Agree; A Agree; NC No Comments; D Disagree; SD Strongly Disagree) 
generating fund from libraries and it is represented by $89.3 \%$ of respondents, followed by economic usage and collection development from book donation camps. Paid individual membership can also be given to student community from other institutions and paid internet services was also recommended by $74.4 \%$ of respondents and this is already in practice as Institutional Membership among institutions. But practically, it is used by the faculty and this can be further extended to student community with limitations. This helps the students to visit academic libraries in their proximity. Least preference was given to physical advertisements.

The mean and standard deviation were also calculated based on the responses and ranks were assigned accordingly. The mean and standard deviation and rank were shown separately under two different categories of designation namely librarian and assistant librarian in Table 10.

From the Table 10, it is evident that librarians and assistant librarians have lot of differences in their opinion on fund generation strategies though much preference was not given to physical advertisements and paid services to non-members.

\section{Findings}

The following are some of the findings

- The term Sustainable Development is beneficial and $83.3 \%$ of the respondents give more significance to fund generation

- There exists difference between the opinion among professionals on fund generation

- With reference to awareness, views and importance of sustainable development most of the responses were similar among designation and gender categories.

- On sustainable development and fund generation responses among librarians and assistant librarians were slightly different.

- Popularization of sustainable development and fund generation should be taken up to benefit the user community and management as $91.5 \%$ of respondents have stated that the awareness should be created for free open source resources.

- With management's co-operation, changes in institutional policies, fund generation strategies will help in sustainable development.

Table 10. Sustainable Development and Fund Generation Vs. Designation

\begin{tabular}{|c|c|c|c|c|c|c|c|c|c|c|c|c|c|c|c|c|c|}
\hline \multirow{2}{*}{$\begin{array}{l}\text { Sl. } \\
\text { No }\end{array}$} & \multirow{2}{*}{ Description } & \multicolumn{8}{|c|}{ Librarian } & \multicolumn{8}{|c|}{ Asst. Librarian } \\
\hline & & SA & A & $\mathrm{NC}$ & $\mathrm{D}$ & SD & Mean & Std. & Rank & SA & A & $\mathrm{NC}$ & $\mathrm{D}$ & SD & Mean & Std. & Rank \\
\hline 1 & $\begin{array}{c}\text { Management or recurring cost is } \\
\text { increasing }\end{array}$ & 7 & 10 & 2 & 0 & 0 & 4.25 & 1.041 & 3 & 14 & 8 & 4 & 2 & 0 & 3.84 & .898 & 7 \\
\hline 2 & $\begin{array}{c}\text { Sustainable development can be attained } \\
\text { by fund generation }\end{array}$ & 8 & 7 & 3 & 1 & 0 & 4.29 & .600 & 2 & 7 & 20 & 1 & 0 & 0 & 4.05 & .780 & 5 \\
\hline 3 & $\begin{array}{c}\text { Sustainable development can be attained } \\
\text { by economic usage and saving }\end{array}$ & 7 & 10 & 2 & 0 & 0 & 4.39 & .685 & 1 & 13 & 12 & 2 & 1 & 0 & 3.89 & 1.243 & 6 \\
\hline 4 & $\begin{array}{l}\text { Physical advertisings in library campus } \\
\text { can be allowed for income generation }\end{array}$ & 2 & 8 & 6 & 3 & 0 & 3.68 & .863 & 10 & 3 & 15 & 7 & 3 & 0 & 3.42 & .838 & 10 \\
\hline 5 & $\begin{array}{l}\text { Book donation camps can be allowed } \\
\text { for collection development }\end{array}$ & 7 & 9 & 2 & 1 & 0 & 4.04 & 1.138 & 6 & 10 & 15 & 1 & 0 & 2 & 4.26 & .562 & 1 \\
\hline 6 & $\begin{array}{c}\text { Collection of endowment funds from } \\
\text { users }\end{array}$ & 6 & 7 & 4 & 2 & 0 & 4.14 & .705 & 4 & 9 & 18 & 1 & 0 & 0 & 4.11 & .875 & 3 \\
\hline 7 & $\begin{array}{c}\text { Collected Endowment funds should be } \\
\text { invested and interest alone should be } \\
\text { utilized }\end{array}$ & 3 & 13 & 3 & 0 & 0 & 4.11 & .416 & 5 & 4 & 24 & 0 & 0 & 0 & 4.05 & .524 & 4 \\
\hline 8 & $\begin{array}{c}\text { Paid extension or reference services to } \\
\text { non-members can be provided }\end{array}$ & 3 & 10 & 5 & 1 & 0 & 3.86 & .705 & 9 & 7 & 17 & 3 & 1 & 0 & 4.11 & .809 & 2 \\
\hline 9 & $\begin{array}{l}\text { Paid internet services for non-members } \\
\text { in lean period can be permitted }\end{array}$ & 7 & 5 & 4 & 2 & 0 & 3.93 & 1.152 & 8 & 8 & 12 & 3 & 4 & 1 & 3.63 & 1.065 & 8 \\
\hline 10 & $\begin{array}{l}\text { Individual membership on paid basis } \\
\text { to students from other educational } \\
\text { institutions can be encouraged }\end{array}$ & 3 & 8 & 3 & 1 & 4 & 3.93 & .898 & 7 & 9 & 15 & 4 & 0 & 0 & 3.63 & 1.422 & 9 \\
\hline
\end{tabular}




\section{Conclusion}

Sustainable Development should be taken up by Library Professionals with inspiration as a daily routine and not as an extra-curricular, time-consuming activity. Moreover, users should also be educated by posters, lectures, banners, seminars workshops etc. periodically as a part of orientation programme. Integrated Sustainable development plan, with features like energy generation, economic usage of resources, technological sustainability, environmental sustainability, green infrastructure development, etc. With management's co-operation, efforts and motivation, Library professionals can contribute for long and sustainable benefit for users, management, professionals, environment, and future generations and globe on the whole.

\section{References}

1. Bericht B., A Report on World Commission on Environment and Development: Our Common Future, 1987.
2. Einesberg S., The 3 R's still rule. The Green Life; A Journal of Sorts, 2008. Available from:http://www.nrdc.org/ thisgreenlife/0802.asp

3. American Policy Association: Policy Guide for Planning for Sustainability, 2000.

4. Lacy, P., et al. A New era of Sustainability in United Nations Global Compact - CEO Study 2010, 2010.

5. Meattle K., How to grow your own Fresh Air. TED Talks, 2009. Available from https://www.ted.com/talks/ kamal_meattle_on_how_to_grow_your_own_fresh_ air?language $=e n$

6. Kuhn H. C., An Appeal for Endowment Fund.The Endowment Fund, 1898

7. Swan, J., 25 Proven Ways to get more money for your library Neal-Schuman Publishers, 411 p, 2 002. \$69.95. ISBN 1-55570-433-6. LC 2002-005813.

8. Steele V., Elder Stephen D., Becoming a Fundraiser: The Principles and Practice of Library Development, ALA, 2000.

9. Coakes S. J., Steed L. G., SPSS Analysis without Anguish. John Wiley \& Sons, 2003.

10. Cronbach L. J., Shavelson R. J., My Current thoughts on Coefficient Alpha and Successor Procedures. Educational and Psychological Measurement, Vol 64(3), p. 391-418, 2004. 